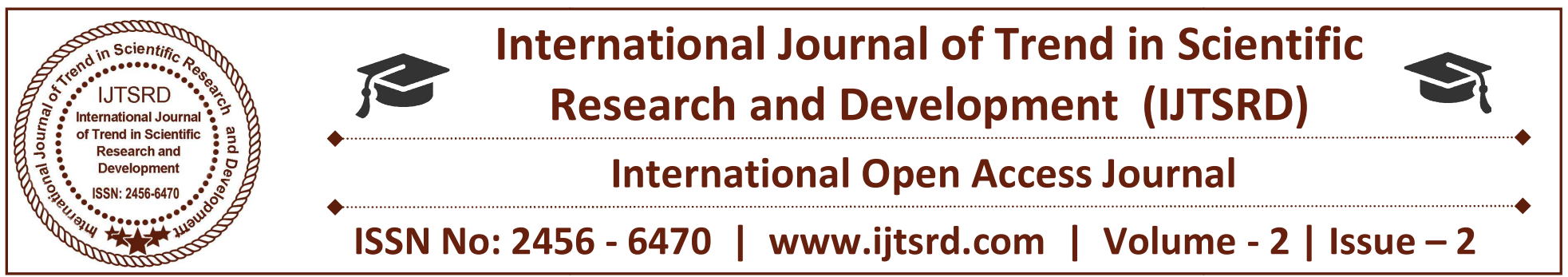

\title{
Casualisation of University academic labour and its effect on University Performance in Kenya. A case of Universities in Nakuru County - Kenya
}

\author{
Dr Charles Mulandi Zakayo \\ Sr Lecturer, School of Business and Economics, Kabarak University, Kenya
}

\begin{abstract}
\end{abstract}
Development of any Country is pegged on the quality of its higher education. In Kenya, some decades ago, Quality was embraced in all Universities through vigorous vetting of programs offered. Programs were matched with existing quantity and competency of lecturers to run such programs. With increased demand of higher education in Kenya and Universities establishing many satellites campuses without considering availability of required facilities and sources of qualified teaching staff, quality of higher education may have been compromised. This prompted the researcher to establish the effects of part-time lecturers on the academic performance of Kenyan Universities. The specific objectives of the study were:- To establish the effects of part-time turnover rate on performance of the University, to examine the effect of part-time teaching staff service delivery on University performance and to examine the effects of part-time teaching staff competencies on University performance. To achieve this, the researcher adopted descriptive research design. The target population was all the nine Universities in Nakuru town. The targeted respondents were the 37 heads of departments (HODs) in these Universities. The study adopted a census survey technique. The data collected with questionnaires was analyzed by the help of descriptive and inferential statistics with the aid of 'SPSS' a statistical Package for Social Sciences. The finding showed turnover $(\mathrm{r}=.688$, $\mathrm{a}=0.001)$, Service delivery $(\mathrm{r}=.803, \mathrm{a}=0.01)$ and Competence $(\mathrm{r}=.688, \mathrm{a}=0.001)$. This indicated positive correlation between part-time teaching and University academic performance. Results of Multiple regression analysis were:-turnover $(\beta=0.134)$, service delivery $(\beta=0.600)$ and competence $(\beta=0.170)$ which further, indicating relationship between part-time teaching and University performance.

Keywords: Part-time teaching staff, service delivery, competences, turnover, performance

\subsection{Introduction}

Short term employment has become a world practice in the past three decades and is perceived to be resulting from continuous changes in the work arrangements (Foote, 2004). Institutions of higher learning in developing countries are increasingly faced with shortage of qualified and experienced full time teaching staff. Many people are noticing the power of higher education. This is projected by the large number of people joining University education. In order to cater for this demand, Universities are over-stretching beyond their abilities to provide expected quality education. These Universities heavily rely on part-time teaching staff to cut the cost of running education programs. These are just, visiting lecturers whose relationship with the University is the hour given to each of them to teach and the pay for that hour only. Part-time lecturers are less connected with their colleagues and students. Relying on part-time teaching staff contradicts the widely accepted principles for good practice in higher 
education. These principles include institutional commitment to hiring the best available teachers, institutional support for all faculties and enabling frequent student-faculty contact in and out of classes. Knowing faculty members well, enhances students' intellectual commitment, encourages them to think about their own values and therefore is the key factor in students' motivation and academic achievement. The University that relies heavily on part-time lecturers may be hampered in its attempt to promote student learning.

The history of increased students' numbers in Kenyan Universities and need for part-time staff was first influenced by the second president of Kenya, his Excellency Daniel Toroitich Arap Moi, who during his term as the president opened up many Universities in Kenya. Full -time lecturers could not handle alone the increased teaching task, therefore part- time lecturers had to be engaged to assist in teaching in these Universities.

The third President of Kenya his excellent Mwai Kibaki (2003-2007) introduced free Primary education and free tuition in secondary education in public schools (2007-2008). Free Primary education increased students' enrolment from five million in 2003 to more than nine million to day (2017). This together with free tuition in Secondary schools increased the number of students in Kenyan Universities thus, increasing demand for part-time lecturers. In the modern society, higher education has become a critical rite of passage (Pityan, 2004). According to Rukangu and Makokha (2001), the ultimate goal of University education is to provide both knowledge and skills to the learners that make them meet the global labour market challenges.

In 1960s there were only seven Universities in Africa, however by 2005 there were 401 Universities in Africa (Kihara 2005). In 1984 Kenya had only two public Universities but currently (2017) there are twenty two public Universities and fourteen chartered private Universities in Kenya.

The objective of the part-time lectureship is to enable the Universities to handle the bulky teaching load effectively and economically. Universities are required to get enough qualified lecturers on full -time basis, but due to lack of enough qualified lecturers in the market and also for economic reasons they opt to supplement their teaching staff by bringing on board part-time lecturers.

\subsection{Statement of the problem}

Most institutions of higher learning are making use of part-time lecturers in order to supplement their fulltime teaching staff and also to reduce the cost of labor (Alston 2010). High growth in the number of Universities in Kenya has considerably led to increased accommodation of part-time teaching staff in order to assist them handle their increased workload as well as a cost cutting strategy. Though part-time lecturers are increasingly used in Kenyan Universities, most of them have multiple contracts in different Universities (moonlighting) thus, failing to have enough time to settle, relax and prepare for their classes. They also prioritize their 'employer University' before any other, thus compromising further their quality performance in the University where they teach on part-time basis. This study aimed at establishing the effect of casualisation of academic labour on University academic performance. A case of Universities in Nakuru County- Kenya.

\subsection{Objectives of the study}

(i) J To determine the effect of part-time teaching staff turnover rate on University performance.

(ii) To examine the effect of part-time teaching staff service delivery on the University's performance

(iii) To examine the effect of teaching competencies of part-time staff on University performance.

\subsection{The scope of the study}

The study focused on the challenges faced by Kenyan Universities in managing performance of part-time teaching staff and their effects on University performance. It concentrated on the Universities located within Nakuru town.

\subsection{Literature review}

Abrupt expansion of tertiary education and the resultant need for Universities' flexibility to accommodate it, has given rise to the casualization of academic labour in Universities. Universities are over-stretching their capabilities in attempt to meet this demand. The question raised here is, are these Universities able to maintain global educational standards?. Beside Universities trying to supplement academic labor demand by use of part-time lecturers, they also use it as a cost cutting strategy. The 
Institution may not get the best value out of the intellectual capital of such staff. The relationship between them and the University is very minimal, they have multiple contracts with different Universities and their engagement with their students is only confined within the four corners of classroom.

\subsection{An historical perspective}

The development of education in Kenya can be put into three distinct periods:- the pre-colonial, colonial and post-colonial periods. The pre-colonial education was holistic in nature. It was provided within the context of social and economic set up. It was all embracing and relevant along age groups and gender lines. It was designed to ensure that society was able to manage its environment and other natural resources in a beneficial and sustainable manner, live in harmony, practice natural social responsibility and sustain a high degree of moral and ethical values. Moral and ethical values were known and accepted as a way of life by all (Manyasi, 2010). Kenya was declared a British protectorate in 1895 and made a British colony thereafter. British government imposed its own education policies and practices in the process of destroying the African traditional education system. This education system was exclusive, discriminatory and organized along racial lines. There were segregated schools for Europeans, Asians and Africans.

Upward educational mobility was restricted for Africans through rigorous examination system. This restricted the Africans' access to higher education. Some Christian churches made efforts to provide higher education to Africans but was far inadequate. This led to lack of skilled indigenous personnel at the dawn of political independence to manage and stimulate economic growth (Eshiwani 2009). On attainment of political independence 1963, the Kenya government produced a blue print to guide the development process entitled "African Socialism and its Application to planning in Kenya." Here education and training of skilled manpower became one of the pillars of development process. The long term objective of higher education is to enhance the ability of Kenyans to preserve and utilize the environment for productive gain and sustainable livelihoods. Development of quality human resource is the key to attainment of national goals for industrial development and it is necessary for development and protection of democratic institutions and human rights. The dawn of political independence brought with it great enthusiasm amongst Kenyans for education.

The government came up with programs to remove injustice of the past and assist Kenyans to access education. Since then Kenya has witnessed a rapid growth for demand for education. Mwiraria (1994) indicated that in a steady growing population the government should have a policy that aims at increasing access to higher education.

The ministry of education is empowered to make policies and regulation to govern the preparation and approval of curriculum, syllabuses, books and other educational materials. At independence, the education system was structured on British model of 7-4-2-3 (seven years in primary education, four years in secondary education, two years in high school and three years' of bachelor's degree). In 1992, there was a shift from 7-4-2-3 model of education to 8-4-4 model of education (eight years of primary education, four years of secondary education and four years of bachelor's degree). This is an American model of education (Republic of Kenya (2006). This new model of education resulted to drastic increase in University enrolment.

University enrolment was further enhanced by the opening up of the Public Universities to privately sponsored students under the " parallel degree programs". Since this increased enrolment was not correspondingly accompanied by increased employment of teaching staff, the result was a steady decline in education quality (Mwiria \& Nyukuri 1994).

In Kenya there are Public Universities and Private Universities. The concept of public University refers to an institution of higher learning established and fully funded by the state. The Acts of parliament that established these Universities clearly spell out their vision, mission, powers, governance and financing.

Private Universities are those institutes of higher learning that are owned by individuals or religious organizations.

Higher education in Kenya can be said to have started with the establishment of Royal Technical College of East Africa in 1956 (Olel, 2006). Initially it was meant to provide instruction in courses leading to Higher National Certificate offered in Britain to prepare matriculated students through full- time study for University degrees in engineering and 
commercial courses not offered by Makerere University (mwiria \& nyukuri 1994). This college was elevated to the University college of Nairobi in 1963. In 1970, University of Nairobi was established by an Act of Parliament. The University of Nairobi has since then grown to be the largest University in Eastern and Central Africa with over 30,000 students (Olel, 2006)

At the time of attainment of political independence in 1963 Kenya had only one University level institution which had enrolment of about 1000 students by 1970 (Manyasi, 2010). Since then however there has been a tremendous expansion in higher education not only in terms of number of institutions but also in the scope of degree programs and students enrolment. Some of them are:- Moi University (1984), Kenyatta University (1985), Egerton University (1987), Jomo Kenyatta University of Science and Technology (1994), Maseno University (2000) and Masinde Muliro University of Science and Technology (2007). These Universities have 16 University affiliates.

Beside Public Universities, there are 14 chartered Private Universities in Kenya and offer their own degrees programs (Olel, 2006). These Universities operate under close policing by Commission for Higher Education (CHE-The national higher education accrediting body). This body ensures institutions adhere to strict standard and regulations.

\subsection{Theoretical Review}

Various theories have been advanced to explain the effects of part-time lecturers on University performance. Relevant theories have been reviewed to help the researcher understand better the general perspectives of part-time lecturers on University performance.

\subsection{Social Exchange Theory}

Social exchange theory states that individuals form relationships with those who can provide valued resources. In exchange for these resources, individuals reciprocate by providing resources and support (Gouldner, 1960). Individuals exhibit greater commitment to an organization when they feel supported and rewarded (Rhoades, Eisenberger \& Armeli 2001). This commitment, in turn, manifests itself in increased performance and other work behaviors that benefit the organization. Recent research indicated that contingent workers are less committed to their employers and perform at lower level than permanent workers (Connelly \& Gallagher 2004, Linden et al 2003 \& Pearce 1993). Contingent workers have a negative effect on other employees within the organization (Kalleberg, 2000, Pearce 1993). Permanent employees where a large number of contingent workers are employed feel insecure about their status in their job thus weakening their trust to their organization This leads to low work performance( Kraimer, Wayne, Liden \& Sparrowe 2005). Though much is known about contingent workers in other organizations, very little is known about the effect of contingent appointments in University education. Bettinger \& Long (2005) found negative relationship between the number of parttime teaching staff and their turnover and students' graduation rate. Umbach (2007) observed that parttime lecturers interact less with students and spend less time to prepare for their classes than permanent lecturers.

\subsection{Equity theory}

Equity theory was developed by Stacy Adams in 1963. Adams asserted that employees seek to maintain equity between the inputs that they bring to a job and the outcomes that they receive from it against the perceived inputs and outcomes of others. The belief is that people value fair treatment. The structure of equity in the workplace is based on the ratio of input to outcomes. The inputs are the contributions made by the employees to the organization. Equity theory predicts that, short term workers who perform comparably task equally as the permanent employees, but receive lower pay than the full -time employees, may respond by reducing their output (Cascio 1991).

\subsection{Theory of work adjustment (TWA).}

The relationship between the employee and organization is also reviewed by the theory of work adjustment (Dawis et al, 2004). It places emphasis on the interaction and how the workers change to fit into workplace. This theory highlights the congruence between the requirements of the organization and the requirements of the employees. Employees' needs and expectations should be fulfilled by the organization (Dawis, 2004). Organization also has needs that should be fulfilled by the employees. If the needs and expectations of employees are not met bring dissatisfaction that may lead to quitting of employees (Dawis, 2004, Dawis et al, 1968). 


\subsection{Issues and challenges of University Education.}

According to Ngara (1995), African Universities have four primary functions :- promoting human resource development by producing high level human power in all fields of study, research and dissemination of knowledge, fostering moral values and raising social consciousness and consultancy services. Some of the issues and challenges that have to be addressed by Universities in Africa so as to meet the above expectations include :- inadequate funding and the slow pace of release of the little funds to which the Universities are entitled. Staff with low morale as a result of deterioration of their working environment that leads to leaving their institutions for greener pasture elsewhere and Lack of enough physical facilities to accommodate the ever increasing demand for University education in the society. These lead to loss of public confidence in Kenyan Universities as a result of declining academic standards. There are heated debate on matters relating to the standards of University courses / degrees, their scope and relevance to the current needs in the industry (Ngara, 1995, Chacha 2002, Lungwangwa, 2002, Tiyambe, 2004 and Mwiria et al, 2007).

\subsection{Part-time employment}

The use of contingent staff in higher education in the US has tremendously grown over the past three decades. In 1975 only $30.2 \%$ of staff was employed on part-time basis but by 2013 according to data compiled by AAUP from the integrated post secondary education system (IPEDS) part-time staff represented approximately $78 \%$ of all staff members in USA. The growth of part-time teaching staff has occurred despite believes that, these staff receives low pay, no benefits, inadequate working conditions and little or no opportunity for career development.

In Kenya, increase in use of part-time teaching staff can be traced back to 1970s as a response to increased enrolment of students in Kenyan Universities. The increased use of part-time staff may affect the quality of education. Literature shows that there are benefits and costs resulting from this shift in staff composition. According to Wyles (1998) the shift to hiring of part-time staff in large numbers is consistent with national employment pattern of downsizing, subcontracting and outsourcing labor to cut operating costs. Banachowski (1996) contends that the most often reported reason and benefit for increasingly utilization of part-time employees is economic savings. This trend reflects in the overall United State economy (Pederson 2001). A study conducted by Louziotis (2000), indicated that use of part-time staff has also grown because more people need to be educated in different way on more subjects because the workplace in twenty- first century demand more highly trained and skilled workers than ever before.

Part-time staff maintain regular working hours where they are permanently employed this is why they are willing to teach on part-time during traditional nonbusiness hours such as nights and weekends to meet the increased demand for off-hour classes for working students.

\subsection{Empirical study}

Turnover is initiated by poor management or lack of satisfaction by the part-time teaching staff. Turnover leads to loss of financial and human capital (Droege and Hobbler 2003).

Studies have shown that full-time faculty take longer office hours, spent more time in class-work preparation and attend curriculum development-based departmental meetings. They take opportunities for professional development and help in advising students (Friedlander, 1980). This is not the case with part-time teaching staff. In 1988 California law mandated staffing ratio of no less than $70 \%$ full- time staff and $30 \%$ part-time faculty at community colleges throughout the state.

The study conducted in Midwestern University by Harrington and Timothy (2001) showed that increased use of part-time lecturers to teach first semester students decreases the chance of students' retention in later semesters in the University.

Quality teaching service enables Universities to provide competent graduates to the society thus contributing greatly to socio-economic development in the country.

\subsection{Conceptual Framework}

Independent variables examined were turnover rate, service delivery and competence while the dependant variable was performance 


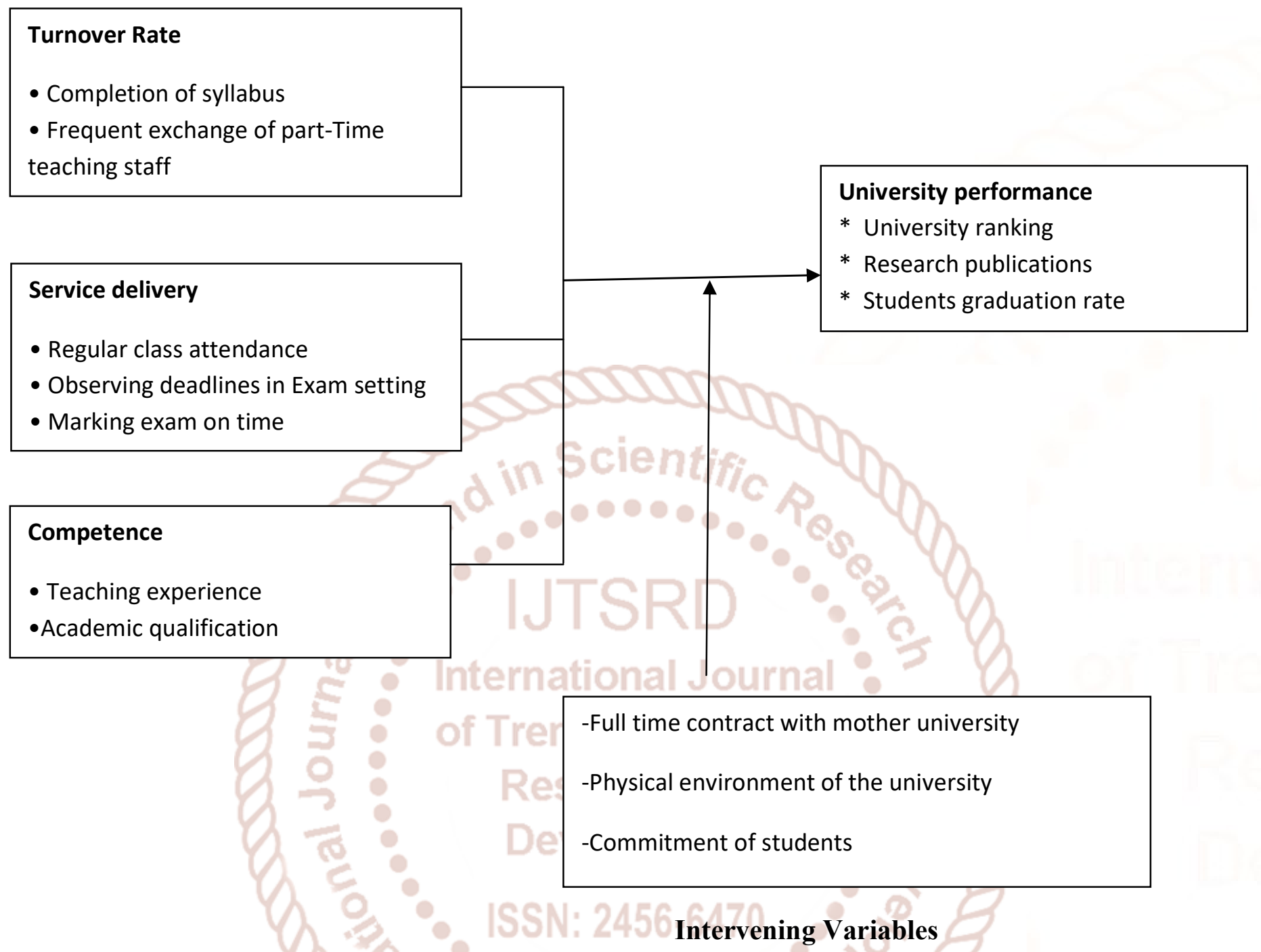

Source: Researcher (2017)

\section{Research Methodology}

The research employed descriptive survey design. The study targeted the 9 Universities within Nakuru town with total of 37 heads of departments/coordinators. The researcher included all the nine Universities and their 37 heads of departments/ coordinators in his study since the population was small and manageable (Census survey). The study targeted the Heads of departments /Coordinators because were the people most conversant with the subject matter of the study. 
International Journal of Trend in Scientific Research and Development (IJTSRD) ISSN: 2456-6470

\subsection{Target population table}

\begin{tabular}{|l|l|l|}
\hline & Universities in Nakuru town & HOD/Coordinators \\
\hline 1 & Kabarak University & 5 \\
\hline 2 & Egerton University & 7 \\
\hline 3 & Kenyatta University & 1 \\
\hline 4 & Kenya Methodist University & 1 \\
\hline 5 & St Paul University & 1 \\
\hline 6 & University of Nairobi & 1 \\
\hline 7 & Presbyterian University & 1 \\
\hline 8 & Mount Kenya University & 18 \\
\hline 9 & Jomo Kenyatta University of Agriculture Science and Technology & 2 \\
\hline & Total & 37 \\
\hline
\end{tabular}

Data was collected by use of questionnaires after testing their validity and reliability at cronbach's Alpha 0.907 .

\subsection{Data Analysis.}

3.12 Findings of the study

The findings of this study were based on research questions and the responses obtained from the HODs/Coordinators.

The study employed descriptive statistics and inferential statistics. Descriptive statistics included:frequencies, percentages and statistical mean while inferential statistics included:- spearman's correlation and regression.

\subsection{Education level of Respondents}

\section{HOD/Coordinators}

Masters

\section{Frequency}

Percentage

6.9

86.2

\subsection{Response rate}

29 respondents filled and returned the questionnaires. Response rate of $81 \%$ was attained.

\section{Professor}

25

The study showed that $6.9 \%$ of the HOD/Coordinator had Masters level of education, $86.2 \%$ had doctorate level of education while only $6.9 \%$ had attained the level of professor.

\subsection{Staff Turnover}

The study addressed the factors contributing to high labor turnover of Part-time teaching staff and its effect on University performance.

Statements

\begin{tabular}{|c|c|c|c|c|c|c|}
\hline $\begin{array}{l}\text { SA } \\
\text { Freq }\end{array}$ & $\begin{array}{l}\text { A } \\
\text { Freq }\end{array}$ & $\begin{array}{c}\mathrm{N} \\
\text { Freq }\end{array}$ & $\begin{array}{c}\mathrm{D} \\
\text { Freq }\end{array}$ & $\begin{array}{l}\text { SD } \\
\text { Freq }\end{array}$ & $x^{2}$ & $\begin{array}{l}\text { P- } \\
\text { Value }\end{array}$ \\
\hline$(\%)$ & (\%) & (\%) & $(\%)$ & $(\%)$ & & \\
\hline
\end{tabular}

- There is high part-time staff turnover Rate In the University

- High part-time teaching staff turnover

Decreases university performance

- Part-time staff turnover leads to

Unbudgeted expenses

- Is hard for University to replace part

Time staff immediately they leave 19.7930 .001

$\begin{array}{lcccccc}- & 17(58.6) & 3(10.3) & 2(6.9) & 7(24.1) & 19.414 & .000 \\ - & 14(48.3) & 3(10.3) & 9(31) & 3(10.3) & 11.690 & .009 \\ - & 14(48.3 & 3(10.3) & 9(31) & 3(10.3) & 11.690 & .009 \\ - & 2(6.9) & 15(51.7) & 3(10.3) & 6(20.7) & 3(10.3)\end{array}$


$58 \%$ of respondents agreed that there is high turnover rate of part-time time teaching staff in the Universities $\left(\chi^{2}=19, \mathrm{P} \leq 0.001\right)$.The majority of respondents agreed that high turnover of part-time teaching staff affects negatively the University performance $(\chi 2=11, \mathrm{P} \leq 0.009)$.

$48 \%$ of respondents agreed that part-time staff turnover leads to unbudgeted expenses $(\chi 2=11, \mathrm{P} \leq 0.009)$. The findings also show that Universities find it hard to immediately replace the part-time staff who leave the University.

\subsection{Part-time lecturers' service delivery}

The second objective of the study was to examine the level of part-time service delivery on the University performance.

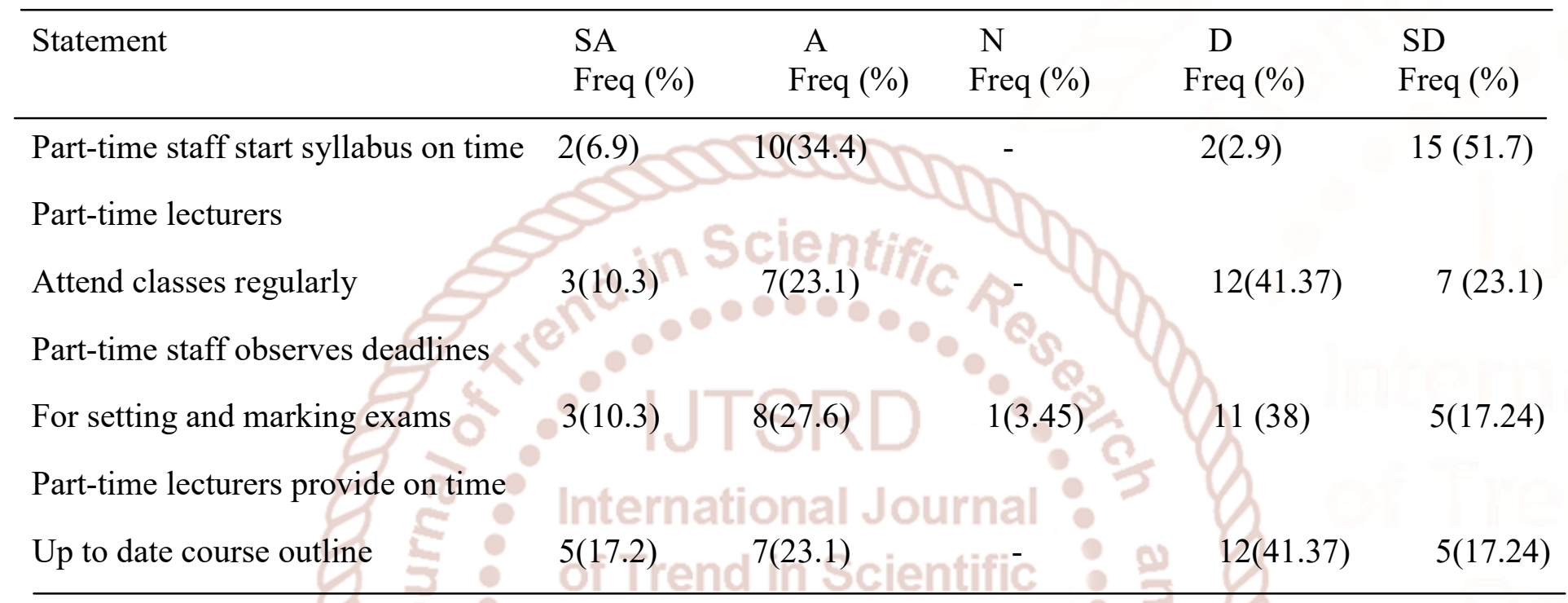

Source: Researcher 2017

The results in the table show that $58.6 \%$ of the respondents disagreed that part-time staff start syllabus on time, $65.5 \%$ of the respondents disagreed that part-time staff attend classes regularly, $55.2 \%$ of the respondents disagreed that part-time staff observe deadline for setting and submitting exams and $58.6 \%$ of respondents disagreed that part-time staff provide up to date course outline on time. This indicates poor service delivery of part-time teaching staff.

\subsection{Part-time lecturers Competence}

The third objective of the study sought to examine the level of teaching competencies of part-time staff on the university performance.

All the respondents agreed that the part-time teaching staff are qualified to teach in the University and have the required experience.

\subsection{Performance}

The researcher sought to measure the attitudes of the respondents on the performance of part-time lecturers and their effects on University performance. 
SA

Freq

$(\%)$

$7(24.1)$

$19(65.5)$

3(10.3)

$\mathrm{D}$

SD

$\chi^{2}$

p-

Freq Freq Freq Freq

$(\%)$

$(\%)$

$(\%)$

$(\%)$

High rate of part-time staff turnover

affect University performance

The relationship between mgt

and part-time staff affect the

General performance of University

$10(43.5)$

$14(48.3)$

$3(10.3) \quad 2(6.9)$

$-\quad 13.621$
$-\quad 10$

.003

Performance of part-time staff affect

the performance of the University

$8(27.6) \quad 21(72.4)$

$-$

5.828

.016

Motivating part-time lecturers leads to commitment to university performance

\section{Source: Researcher 2017}

Respondents agreed that high rate of part-time turnover affect the University performance $(\chi 2=14, \mathrm{P} \leq 0.001)$. $65 \%$ of the respondents agreed that the relationship between Part-time teaching staff and management affect the general performance of the university $(\chi 2=13, \mathrm{P} \leq 0.009)$. Majority of respondents have also agreed that motivating part-time teaching staff leads to increased commitment to University performance $(\chi 2=7, P \leq 0.002)$.

Further statistical analysis was done to explore possible relationship between variables.

\subsection{Inferential statistics}

Referential statistics was used to draw inferences on responses received on the subject of the study (population).

\subsection{Correlation analysis}

Correlation coefficient measures the strength of association between two variables. Research wanted to find out the correlation between staff turnover, service delivery and staff competence with University performance.

Correlation results

\begin{tabular}{|c|c|c|c|c|c|}
\hline & & Turnover & Service delivery & Competence & Performance \\
\hline \multirow[t]{3}{*}{ Turnover } & $\begin{array}{l}\text { Pearson } \\
\text { Correlation }\end{array}$ & 1 & .517 & .343 & .503 \\
\hline & Sig. (2-tailed) & & .004 & .069 & .005 \\
\hline & $\mathrm{N}$ & 29 & 29 & 29 & 29 \\
\hline \multirow[t]{3}{*}{ Service delivery } & Pearson & .517 & 1 & .788 & .803 \\
\hline & $\begin{array}{l}\text { Correlation } \\
\text { (Sig. 2-tailed) }\end{array}$ & .004 & & .000 & .000 \\
\hline & $\mathrm{N}$ & 29 & 29 & 29 & 29 \\
\hline \multicolumn{2}{|c|}{ Competence Pearson } & .343 & .788 & 1 & .688 \\
\hline & (2-tailed) & .069 & .000 & & .000 \\
\hline
\end{tabular}


International Journal of Trend in Scientific Research and Development (IJTSRD) ISSN: 2456-6470

$\mathrm{N} \quad 29$

Performance
29

.503

.005

29
29

.803

.000

29
29

.688

.000

29

Correlation is significant at the 0.01 level (2-tailed)

Source Researcher 2015

The correlation summary indicates a strong significant association between the independent and dependent variables. Correlation analysis has shown that high turnover rate of part-time lecturers has a significant effect on the University performance $(\mathrm{r}=0.503, \mathrm{a}=0.005)$. About service delivery, the correlation results indicated a significance relationship $(\mathrm{r}=0.803, \mathrm{a}=0.011)$. This shows significant relationship between part-time lecturers' commitment to providing quality service and University performance. The study also found positive significant relationship between part-time teaching staff competency and University performance $(r=.688, a=0.00)$.

\subsection{Regression Analysis}

Regression analysis was used to find the extent to which independent variables affect dependent variables.

Multiple linear Regression Analysis model summary

\begin{tabular}{lllll}
\hline Model & R & R Squared & Adjusted R Squared & Std of Error Estimates \\
1 & .816 & $\mathbf{. 6 6 6}$ ternational J.626 & $\mathbf{1 . 0 6 9}$ \\
\hline
\end{tabular}

a Predictor: (Constant), Competence, Turnover, Service delivery

Source: Researcher 2017.

The adjusted $\mathrm{r}$ square value of , $\mathrm{r}^{2}=.626$ indicate that when all the variables are combined, the multiple linear regression model could explain for approximately $62 \%$ of the variation in part-time lecturers' performance in Universities in Nakuru town -Kenya.

3.21 ANOVA

\begin{tabular}{llccccc}
\hline Model & & Sum of Squares & df & Mean Square & F & Sig. \\
\hline Regression & 56.904 & 3 & 18.968 & 16.613 & .000 \\
Residual & 28.544 & 25 & 1.142 & & \\
Total & 85.448 & 28 & & &
\end{tabular}

a. Predictors: (Constant), Competence, Turnover, Service delivery

b. Dependent Variable: Performance

Source: Researcher 2017

The ANOVA results indicated that there is a significant difference between the mean of factors influencing value when regressed against part time lecturers' performance in Nakuru Town. 


\subsection{Coefficient}

Model

\begin{tabular}{lccccccc} 
& \multicolumn{2}{c}{ Un-standardized Coefficients } & \multicolumn{2}{c}{ coefficients } & \multicolumn{4}{c}{ Statistics } \\
& $\mathrm{B}$ & Std. Error & Beta & $\mathrm{t}$ & Sig & Tolerance & VIF \\
\hline (Constant) & .0508 & .401 & & 1.265 & .002 & & \\
Turnover & .122 & .124 & .134 & .986 & .001 & .806 & 1.241 \\
Service Delivery & .631 & .218 & .600 & 2.892 & .008 & .875 & 1.143 \\
Competence & .158 & .177 & .170 & .897 & .006 & .077 & 1.298 \\
\hline
\end{tabular}

a. Dependant Variable: Performance

Source: Researcher 2017

$Y=0.508+0.122 x^{1}+0.631 x^{2}+0.158 x^{3}$

Where $\mathrm{y}=$ Performance

$\mathrm{X}^{1}=$ Turnover

$\mathrm{x}^{2}=$ Service delivery

$\mathrm{x}^{3}=$ Competence

The findings showed significance between part-time staff turnover and University performance $(\mathrm{p}=0.001)$. The results showed significance between service delivery and part-time lecturer performance $(\mathrm{P}=0.008$ , it also showed significance between competence and part-time lecturers' performance $(p=0.006)$. The standard error was (0.401), being an estimate of the standard deviation of coefficient.

The independent variable which was most important in part-time lecturers' performance was also determined. This was obtained by the beta value where upon the results identified service delivery as the strongest variable in the study followed by competence, and lastly turnover in that order beta values $0.600,0.170$ and 0.134 ). This indicated that variables would change by a corresponding number of standard deviation when the respective independent variable change by one standard deviation..

The VIF value for all the independent variables were less than 10 and the tolerance was also less than 0.1 thus there were no concerns over multi-collinearity. This led to conclusion that part-time teaching staff service delivery, competence and turnover were all important factors in the academic performance of Universities in Nakuru Town Kenya.

\subsection{Conclusion and Recommendations}

The study has shown that part-time lecturers' turnover rate is high in Universities thus affecting the University performance in Nakuru town. Universities should increase the ratio of Full-time to part-time lecturers. Should pay part-time lecturers on time, should improve the relationship with part-time lecturers and provide them with the required facilities for proper teaching and should monitor closely their service delivery. All these will improve the performance of these lecturers and contribute more to the general performance of the University.

The study has shown that these part-time lecturers are competent enough to teach in the University. Therefore Universities can use part-time lecturers as a strategy for cost cutting and maintain good performance if they motivate them well, Provide them with all the facilities required for teaching and monitor their service delivery closely. 
Employees will be willing to stay in a given University provided they get the job satisfaction and as a result they will provide quality service for the University.

\section{REFERENCES}

1. Adams, J. S (1965) "Toward an understanding of inequity". Journal of Abnormal and social Psychology.

2. Banachowki, G. (1996). Perspective and Perception: A review of the literature on the use of part-time faculty in Community colleges. Tolendo, OH; University of Toledo.

3. Barrows, C (2009). "Employee turnover: Implications for hotel managers", FIU Hosp. Rev.

4. Beardwell, J \& Claydon, T. (2007). Human Resource management: a contemporary approach. Pearson Education.

5. Bettinger, E. \& Long, T. L. (2005). Help or hinder? Adjunct professors and student outcome Ithaca, New York: Cornell University.

6. Bolge, R.D. (1995). Examination of student learning as a function of instructor status (fulltime vs part-time) at Mercer Community College. West Windsor, New Jersey: Mercer Community College.

7. Cascio W.F (199I). Applied psychology in personnel management. Prentice Hall, and Englewo. od.

8. Carnoy,M. (1999) Globalization and Educational Reform: What planners Need to know

9. sConnelly, C.E \& Gallagher, D.G. (2004).Emerging trends in short time work research. Journal of Management.

10. Cooper,D.R. Schindler, P. S \& Sun, J. (2006). Business research methods( Vol.9). New York: McGraw- hill.

11. Dawis, R.V, Lofquest, L. H \&Weiss, D.J. (2004). A theory of work adjustment (a revision).

12. Minneapolis, MN: University of Minnesota press.

13. Delamare Le Deist, F. \& Winterton , J . (2005).What is competence? Human Resource Development

14. Droege, S.B \& Hoobler, J. M. (2003)Employees turnover and tacit knowledge diffusion: A network perspective. Journal of Managerial Issues.
15. Foote.D. (2004) "Short term workers: Managing the problem of unscheduled turnover". Department of management and marketing , Middle Tennessee State University, Murfreesboro, Tennessee, USA.

16. Grazulis, S., Chateigner, D., Downs, R.T,Yokochi , A.F.T , Quiros, M. Lutterotti, L \& Le Bail. A. (2009). Crystallography open Database -an open access collection of crystal structures. Journal of Applied Crystallography.

17. Kalleberg A. L (2000). Nonstandard employment relations: part-time, temporary and contract work. Annual Review of Sociology.

18. Kraimer. M.L , Wayne. S.J, Liden R.C \& Sparrowe R.T (2005). The role of job security in understanding the relationship between employees' perceptions of temporary workers and Employees' performance. Journal of applied psychology.

19. Louziotis. D. (2000). The role of adjuncts: Bridging the dark side and ivory tower.

20. Lucia. A.D \& Lepsinger. R. (2009). The art and science of competence models; pinpointing critical IIIC success factor in organization. New York. Pfeiffer.

21. Mayeku. B \& Florence. O. (2011). Policy guidelines and challenges in quality assurance in distance learning in Kenyan Public universities. International journal of information communication technology research, Vol. 8.

22. Mugenda O. M \& Mugenda A.G (1999). Research Methods: Quantitative \& qualitative approach. Act press, Nairobi.

23. Nassiuma, D.K (2000). Survey sampling : Theory and methods .Nairobi: Nairobi university press. Oketch M.O (2000).Costing and Financing Higher Education Development in sub-sahara Africa:

24. Kenya's case in International Education Journal Vol. 4. No 3.

25. Parker R.E (1994). Flesh peddlers and Warm bodies: The Short term help industry and its workers: Rutger University Press, New Brunswick.

26. Pastorino, E.E(1999). Students with academic difficulty: prevention and assistance. APS observer. 
27. Pearce J L (1993). Toward an organizational behavior of contract laborers; Their psychological involvement and effects on employee co-workers. Academy of Management Journal.

28. Pederson R.P (2001). It's time to clean up higher education dirtiest little secret. Community College Week

29. Peteson .M.W \& Augustine C. H (2000). External and internal influences on institutional approaches to student assessment: accountability or improvement?. Research in higher education.

30. Pienaar. C\& Bester C (2008) The retention of academic $\mathrm{s}$ in the early career phase: Empirical research. S A Journal of Human Resource Management

31. Rhoades L. Eisenberger. R \& Armeli. S (2001). Effective commitment to an organization. The contribution of perceived organizational support. Journal of Applied psychology.

32. Rousseau. D.M \& ARTHUR M.B (2001) The boundary less career: A new employment principle for a new organizational era. Oxford University Press.

33. Rukangu B. M. I (2011). Challenges facing students in adapting to mathematics learning in secondary schools in Bungoma South District Kenya.

34. Schuler R.S \& Jackson S.E (2006). Human resource management: Positioning for the 21stcentury, Sixth edition. New York: West Publishing Company

35. Seldin P. (2000). Portfolio s: A positive appraisal. Academy Journal 